\title{
Obesity Surgery Journal-How Are We Doing?
}

\author{
Scott A. Shikora
}

Published online: 29 October 2014

(C) Springer Science+Business Media New York 2014

This past August, the International Federation for the Surgery of Obesity and Metabolic Disorders (IFSO) members got together in Montreal to participate in the IFSO 14, 19th World Congress; it was a great meeting! We all should take our hats off to Professor Michel Gagner and all of the members of the organizing committee for creating and hosting a truly world class conference.

Since a majority of the Editorial Board members attend the World Congress, it is traditionally an opportunity to hold an Editorial Board Meeting. These meetings are an opportunity for me to view the status of the journal and to have the opportunity to pass along this information to the editors. However, it is also important for you, the readers of this journal, to also know how we are doing. So here we go....

The journal had another good year. We had 377 papers submitted for consideration for publication. If the trend holds up, we would receive approximately 750 papers for the year. This well eclipses the last few years (487 in 2011, 536 in 2012, and 604 in 2013). You can also see that the number of submissions increased each year. Despite the increase in submissions, we maintained the quality of the journal by consistently accepting only about $50 \%$ of the papers for publication. However, this could also create a problem. Keeping in mind that the number of journal issues per year and pages per issue must stay fairly constant, as the number of submissions grow (and if we keep the same ratio of accepted to rejected), this will create an increasingly large backlog of papers awaiting publication. That is unfair to most authors who put in a considerable amount of time and effort to make their paper worthy of publication and then have to wait months to see it in print. To prevent this from occurring, the Editorial Board has voted to decrease the percent of accepted papers from $50 \%$ to $30-35 \%$. This should prevent a backlog of papers

\footnotetext{
S. A. Shikora $(\bowtie)$

Brigham and Women's Hospital, 75 Francis Street, Boston, MA 02115, USA

e-mail: sshikora@partners.org
}

awaiting publication. On the downside, it will mean that some marginal papers that previously would have been published will consequently be rejected. However, on the upside, it should improve the overall quality of the journal.

The journal is also blessed by a strong and hardworking team of volunteer Editorial Board members and reviewers. In addition to handling the dramatic increase in manuscript submissions, the editors and reviewers have still been able to cut down the amount of time it takes between when a paper is first submitted and when a final decision is made-from 75.8 days last year to 46.5 days this year. With so many moving parts in the process, that is quite an accomplishment.

The journal is also in more hands these days. Total circulation has increased in every year since 2009. In 2009, there were 6,423 subscriptions. In 2013, it increased to 12,350 subscriptions. I personally would like to see every bariatric surgeon in the world have a subscription to our journal or access to our published articles.

...And here is the most exciting news: Medical journals are judged by something known as the Impact Factor. It is determined by how frequently the published article in a particular journal is cited in other articles. Needless to say, better articles and better journals will have more articles cited than lesser articles and lesser journals. The most recent Impact Factor was for the year 2013. I am extremely happy and proud to announce to you that the 2013 Impact Factor for Obesity Surgery was 3.739, which placed us 15th out of 202 surgical journals. You may be very surprised to see which journals were below us. That is quite a feat!

So, to my Editorial Board and Reviewer friends, I thank you for making me look good! For all the readers of this journal, I want to assure you that we will continue pursue the best ways to continue improving the quality of our beloved Journal.

Warmest regards

Scott A. Shikora, MD, FACS, FASMBS

Editor-in-Chief

Obesity Surgery 